\title{
BIOMETRIC ASPECTS OF FRUIT AND SEEDS Poincianella pluviosa var. peltophoroides (Benth.) L.P. Queiroz
}

\author{
ASPECTOS BIOMÉTRICOS DE FRUTOS E SEMENTES DE Poincianella pluviosa Var. \\ peltophoroides (Benth.) L.P. Queiroz
}

\author{
Vinícius Staynne Gomes Ferreira ${ }^{1}$, Patrícia Carneiro Souto², César Henrique Alves Borges ${ }^{3}$, \\ Amanda de Lira Freitas ${ }^{4}$, Danilo Brito Navais ${ }^{5}$, Marilia Gabriela Caldas Pinto ${ }^{6}$ \\ 1'2,4,6 Universidade Federal de campina Grande, Patos, Paraíba, Brasil, - vinniciustaynne@gmail.com, \\ pcarneirosouto@yahoo.com.br,amandaflorasertao@gmail.com \& marilia.gabriela.caldas@hotmail.com \\ ${ }^{3}$ Universidade Federal Rural de Pernambuco, Recife, Pernambuco, Brasil, - \\ cesarhenrique27@yahoo.com.br
}

${ }^{5}$ Universidade Estadual do Sudoeste da Bahia, Vitória da Conquista, Bahia, Brasil, -danilobn@gmail.com

\begin{abstract}
Species arboreal, native of the Atlantic Forest biome, Poincianella pluviosa var. peltophoroides (Benth.) L.P. Queiroz is widely used in urban landscaping due to the beauty of its flowering and indicated for the recovery of degraded areas as an initial or pioneer secondary species. The objective of the study was to characterize the fruits and seeds biometrically, thus helping in its conservation and improvement. The work was conducted at the Federal University of Campina Grande, campus of Patos-PB, and the fruits were collected manually in matrices located on campus, using as a selection criterion those who were mature. To obtain the biometric data, the fruits were selected and separated 100 fruits and 100 seeds at random. To measure the biometric variables (length, width and thickness) of the fruits and seeds, a digital caliper with a precision of $0.1 \mathrm{~mm}$ was used and then the amplitude of the classes of each analyzed variable was calculated. The results showed that the fruits presented variation in the length of 4.51 to $10.53 \mathrm{~cm}$, however, the predominance of fruit frequency was in the class of $6.03-6.77 \mathrm{~cm}$. The seed length varied from 0.918 to $1.208 \mathrm{~cm}$, with a higher incidence in the class of $1.064-1.112 \mathrm{~cm}$, where it concentrated about $45 \%$ of the seeds. It is concluded that the fruits Poincianella pluviosa var. peltophoroides presented greater uniformity in the variable length and their seeds presented greater uniformity in the biometric variables in which they were evaluated, being this a favorable criterion for its propagation.
\end{abstract}

KEYWORDS: Forest seed, Morphometry of fruits, Sibipiruna.

RESUMO

Espécie arbórea, natural do bioma Mata Atlântica, a Poincianella pluviosa var. peltophoroides (Benth.) L.P. Queiroz, conhecida como Sibipiruna, é muito utilizada no paisagismo urbano devido a beleza de sua floração e indicada para recuperação de áreas degradadas como espécie secundária inicial ou pioneira. O objetivo do estudo foi caracterizar biometricamente os frutos e sementes de Poincianella pluviosa, de modo a auxiliar na sua conservação e melhoramento. O trabalho foi conduzido na Universidade Federal de Campina Grande, campus de Patos-PB, sendo os frutos coletados manualmente em matrizes localizadas no campus, utilizando-se como critério de seleção os que estavam maduros. Para a obtenção dos dados biométricos, os frutos foram selecionados e separados 100 frutos e 100 sementes ao acaso. Para medição das variáveis biométricas (comprimento, largura e espessura) dos frutos e sementes foi utilizado paquímetro digital de precisão $0,1 \mathrm{~mm}$ e, posteriormente calculada a amplitude das classes de cada variável analisada. Os resultados demonstram que os frutos apresentaram variação no comprimento de 4,51 a $10,53 \mathrm{~cm}$, porém, a predominância de frequência de frutos foi na classe de 6,03-6,77 cm. Já o comprimento das sementes apresentou uma variação de 0,918 a 1,208 cm, com uma maior incidência na classe de 1,064-1,112 cm, onde concentrou cerca de $45 \%$ das sementes. Conclui-se que os frutos Poincianella pluviosa var. peltophoroides apresentam maior uniformidade no variável comprimento e suas sementes apresentaram maior uniformidade nas variáveis biométricas em que foram avaliadas, sendo este um critério favorável para sua propagação.

PALAVRAS-CHAVE: Semente florestal, Morfometria de frutos, Sibipiruna. 


\section{INTRODUCTION}

Poincianella pluviosa var. peltophoroides (Benth.) L.P. Queiroz commonly known as sibipiruna, coração-de-negro, sibipira, belonging to the Fabaceae family, is native to the Atlantic Forest, a characteristic Brazilian biome. It is found throughout Brazil, however, with a higher incidence rate on the coast of Bahia, Rio de Janeiro and the Pantanal of Mato Grosso.

The tree is semideciduous and heliophytic, producing a large amount of seeds annually. Its flowers are zygomorphic, terminal racemes, yellow, arranged in conical and erect bunches, occurring in spring. The foliage partially falls in the winter months and is composed of bipinnates, without glands in the rachis and small leaflets. The fruits are dehiscent in a light beige color, like a flattened vegetable, and a diameter about $3 \mathrm{~cm}$. Its size can reach up to 20 meters in height, with a rounded crown of approximately 15 meters in diameter and its orthotropic branches, which grow vertically (HALLÉ et al., 1978; LORENZI, 1992; VIDAL \& VIDAL, 1992; ENDRESS, 1994).

The sibipiruna has countless functionalities, in addition to being highly recommended for urban landscaping, due to the fact that its flowering has a very peculiar characteristic, it can be cultivated in parks and gardens and indicated for the recovery of degraded areas as an initial or pioneer secondary species; its wood can also be used for civil construction, such as rafters and slats, for furniture structure and box structure in general (LORENZI, 2008).

Silva et al. (2009) report that the species has great ecological-environmental benefit in the urban hydrological cycle, since there is an average interception potential of $60.6 \%$ of rainfall, with rainfall ranging from 0.2 to $30.8 \mathrm{~mm}$, which represents an important form of floods containment in the urban environment. Mascaró \& Mascaró (2005) report that the species has a temperature reduction potential in forested roads, in the summer period, of up to $9^{\circ} \mathrm{C}$ and an increase in relative humidity of the air of $15 \%$, mainly because of the density and occupied area for your treetop.

Fruit biometrics provides information for the conservation and exploitation of resources of economic value, allowing a continuous increase in the search and effective use of fruits. Furthermore, it is an important tool for detecting genetic variability within a population of the same species, and the relationship between this variability and environmental factors, as well as genetic improvement. The analysis of fruit pulp yield indicates value both for consumption and fresh fruit, as well as for agro-industrial use (CARVALHO et al., 2003).
The description and the biometric characterization of fruits and seeds can provide important subsidies for the species differentiation of the same genus, taking into account that tropical tree species present great variability in the size of the fruits, in the number of seeds per fruit and in the size of the seeds (CRUZ et al., 2001).

Considering the shortage of information and the need to detect the phenotypic variability of the species Poincianella pluviosa var. peltophoroides the aim of the study was to biometrically characterize the fruits and seeds, thereby helping in their conservation and improvement.

\section{MATERIAL AND METHODS}

The study was carried out at the Rural Health and Technology Center of the Federal University of Campina Grande (UFCG), in Patos-PB, located at the geographical coordinates of $7^{\circ} 01^{\prime} 00$ " $\mathrm{S}$ and $37^{\circ} 17^{\prime} 00^{\prime \prime} \mathrm{W}$. The region is characterized by a BSh-type climate, classified, according to Köppen (ÁLVARES et al., 2014), as hot and dry, with two well-defined seasons, one rainy and the other dry. It has an average annual precipitation of $600 \mathrm{~mm}$, an average temperature of $30^{\circ} \mathrm{C}$ and an air relative humidity average of $55 \%$.

The fruits of Poincianella pluviosa var. peltophoroides were manually collected from two hub trees located 100 meters away from each other, at UFCG center previously mentioned, and were used as the fruit selection criteria those who were ripe. They were conditioned in plastic bags, identified and carried to the Mineral Plant Nutrition Laboratory (LabNut) of the Academic Unit of Forest Engineering / UFCG, on Patos-PB campus. For biometric data acquision, the fruits were selected, ruling out those who were visually identified as damaged, and 100 fruits and 100 seeds were randomly separated (Figure 1).

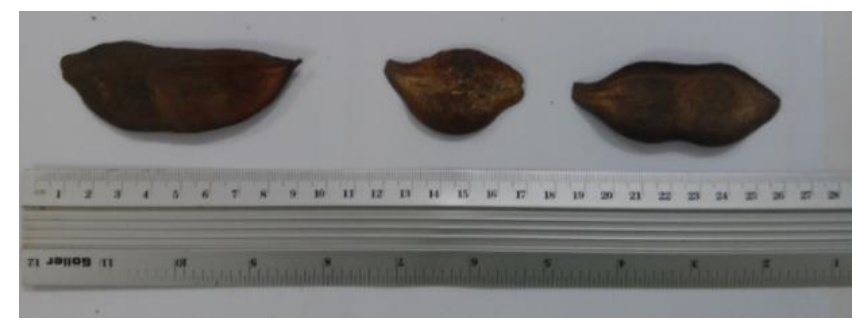

Figure 1. Poincianella pluviosa var. peltophoroides fruits collected in Patos-PB.

\section{Evaluated Parameters}

For the fruits it was determined: the length; the upper, 
median and lower thickness; and the upper, median and lower width, with the aid of a $0.1 \mathrm{~mm}$ digital accuracy caliper (Figure $2 A B$ ), and the same instrument was used for the seeds, in determining the length, thickness and width of each one (Figure $2 \mathrm{CDE}$ ).

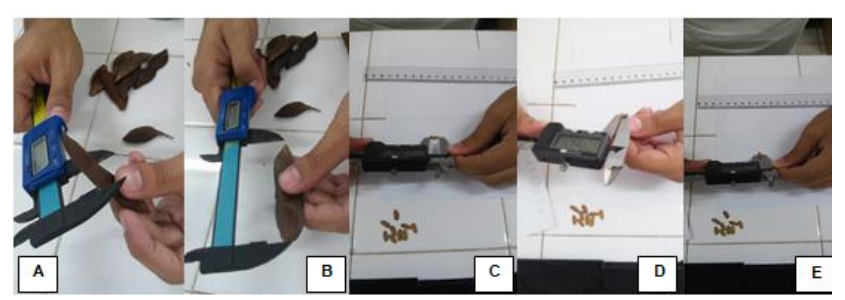

Figure 2. Measurements of fruits and seeds of Poincianella pluviosa var. peltophoroides ( $\mathrm{A}=$ Fruit Diameter; $B=$ Fruit Length; $C=$ Seed Length; $D=$ Seed Thickness; $\mathrm{E}=$ Seed Diameter).

Following Paiva's (1982) methodology, the amplitude was calculated, the relation between the highest and lowest values of the analyzed variables, aiming at the construction of the number of classes (K), through Sturges' equation:

$$
K=1+3,33 \cdot \log n
$$

Where: $\mathrm{K}=$ number of classes; $\mathrm{e} \mathrm{n}=$ number of validated data.

To determine the range of classes, the following formula was used: $h=k$ / at, where: $h=$ range of classes, $k$ $=$ number of classes and at $=$ amplitude of classes. After that, 100 seeds were weighed on an analytical balance scale, with an accuracy of $0.001 \mathrm{~g}$ to determine their mass. Having all the data, the average weight of a seed and the amount of seeds per kilogram were obtained.

The fruits and seed's biometry data of the studied specie were graphically represented by histograms of frequency classes for each variable.

\section{RESULTS AND DISCUSSIONS}

In Figure 3 the biometric data about the fruits length of Poincianella pluviosa var. peltophoroides have been presented. It is noted that the evaluated fruits were sorted into eight frequency classes, with a variation of 4.51 to $10.53 \mathrm{~cm}$ in their length, with the predominance of fruit frequency in the $6.03-6.77 \mathrm{~cm}$ class (20\% of fruits).

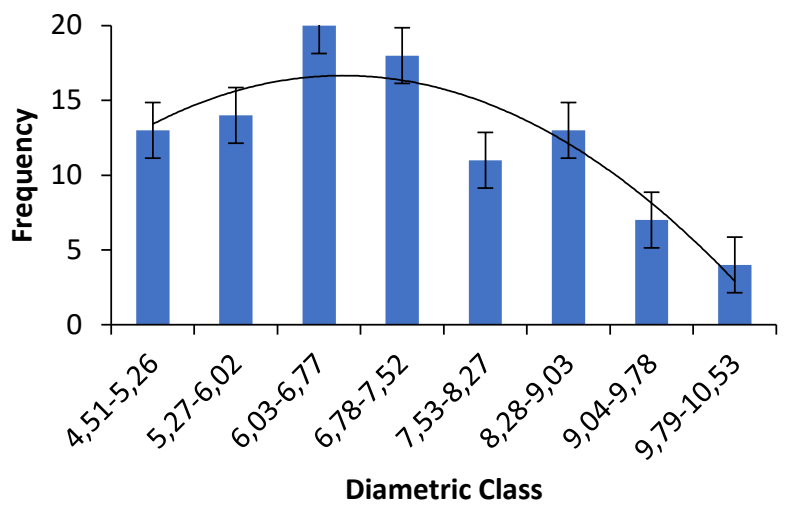

Figura 3. Length $(\mathrm{cm})$ frequency $(\%)$ of fruits of Poincianella pluviosa var. peltophoroides.

It is noticed that the length variable presents a more homogeneous fruits distribution, indicating the same pattern throughout the fructification process. It is common in native tree species this oscillation in the biometric measurements of the fruits and that are due to the effects of environmental factors during the phenological cycle of the species. This is confirmed by Sangali (2008) who says that the variations in fruit size measurements can be affected by envaronmental factors during their flowering and development or, as well as by its high genetic variability of the inserted population.

It is important to highlight that the lack of morphometric studies with Poincianella pluviosa var. peltophoroides makes it difficult to compare the obtained data. A similar situation was reported by Bezerra et al. (2012) where the authors justified that the exposed informations will serve as a basis to investigate the behavior of the species in several regions. For the authors, the species researched and the enviromental, abiotic and biotic factors can contribute to the stablisment of the species' morphometric pattern.

The biometric characterization according to Rodrigues et al. (2006) is importante for differentiation of the species variation intensity related to environmental factors, beside the population reactions, when established in another enviroment, especially when the species has a wide geographical distribution and adaptation to distinct ecosystems. For Soares et al. (2017), the importance of morphological studies results, mostly, from the fact that their knowledge is at the basis of species identification.

Therefore, the informations obtained in the present study allows to identify the variation of fruits morphometric characteristics, which will allow to select those with greater uniformity for later selection and propagation of hub trees with high genetic potential, optimizing thus, the seedlings production. 
About the width of the fruits of Poincianella pluviosa var. peltophoroides (Figure 4), seven classes were registered, ranging from 1.91 to $2.58 \mathrm{~cm}$, with $45 \%$ of the fruits samples belonging to class $3(2.11-2.20 \mathrm{~cm})$. Based on the results, it is noted a high tendency for the fruits to have a width above $2.00 \mathrm{~cm}$.

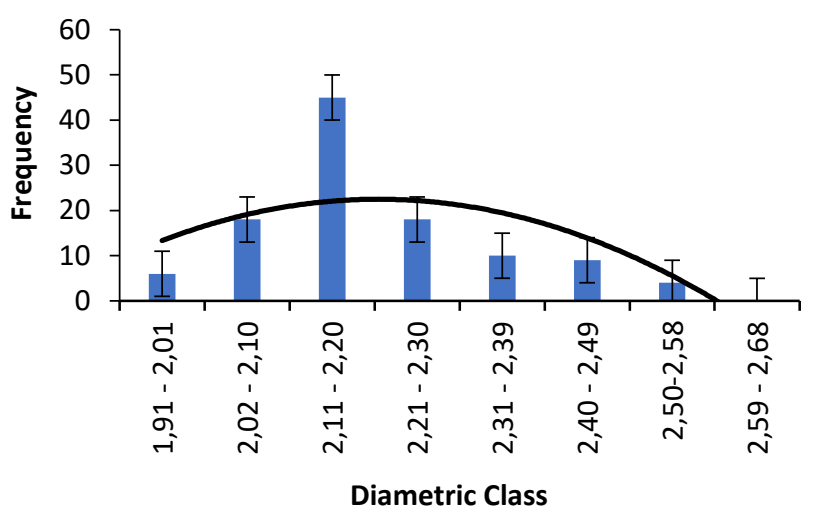

Figure 4. Width's $(\mathrm{cm})$ frequency (\%) of the fruits Poincianella pluviosa var. peltophoroides.

According to Bezerra et al. (2012), the acquisition of these informations is important to confront the biometric distribution of the fruits of a given táxon, classified at the species level or even genus, considering that the production pattern is a function of several factors. Also highlights that the information will serve as a basis to examine the behaviour, since environmental, abiotics and biotics factors can contribute to the stablishment of the species' morphometric pattern.

Based on figure 5 data, it is observed that the fruits thickness of Poincianella pluviosa var. peltophoroides presented four classes, ranging from 0.04 to $0.14 \mathrm{~cm}$, with emphasis on class $1(0.04-0.07 \mathrm{~cm})$ where the predominance of $70 \%$ of the sampled fruits was registered. By the results, it can be inferred that the registered thickness in most of the fruits form a sufficient mechanical barrier in protecting the seed.

Rodrigues et al. (2006) point out that the morphometric data performed on fruits and seeds are taxonomically questionable, due to the strong influence of latitudinal, seasonal and microclimate variations, but they have great biologic significance, related to disperser agents and dispersion syndromes.

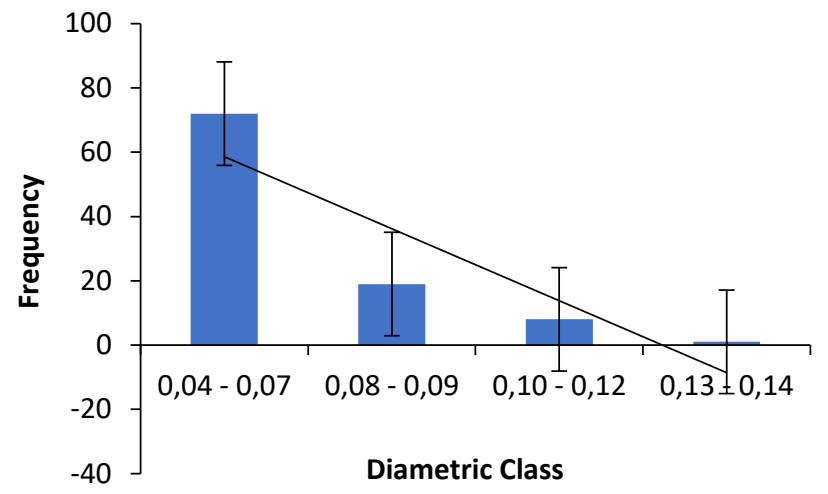

Figure 5. Thickness' $(\mathrm{cm})$ frequency (\%) of the fruits Poincianella pluviosa var. peltophoroides.

Souto et al. (2008) say that in the evaluation of the biometric characteristics of fruits and seeds of a given species, important information is obtained about the variability between individuals in a certain area, still making possible to evaluate plants' ecological aspects.

The seeds lenght showed a range of 0.918 to $1.208 \mathrm{~cm}$, with a higher incidence in the class of $1.064-1.112 \mathrm{~cm}$, where $45 \%$ of the seed were concentrated (figure 6).

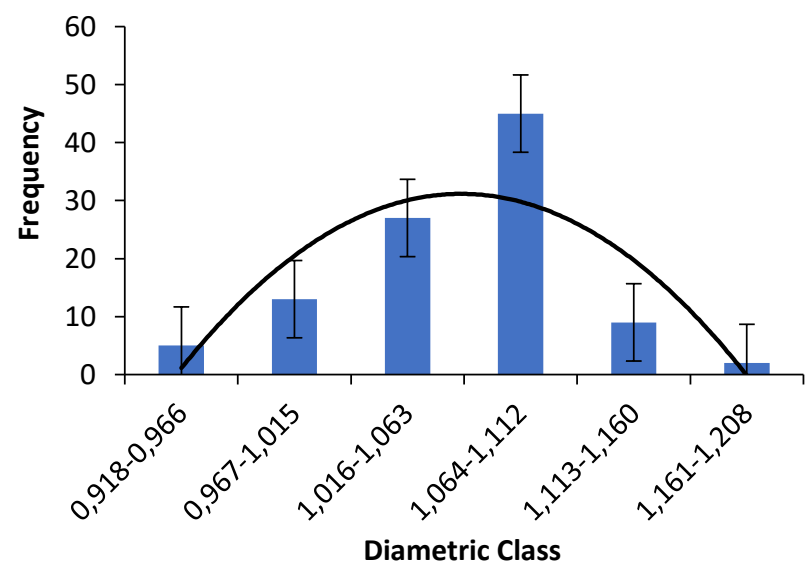

Figure 6. Seeds length $(\mathrm{cm})$ frequency $(\%)$ of Poincianella pluviosa var. peltophoroides.

Lorenzi (2008) characterizes the seeds of the studied species as compressed, irregularly round, transverse, ovate-obovate or orbicular subglobose, with a very rigid, clear, thick or without albumin forehead, provided with a bick in the hilum and margined.

Even being formed by the embryo, reserve tissues and integument, the environment and its varied factors can provide affect the development of the seed, causing a differentiation in its componentes, which may vary between species and within the species itself, in size, shape and colour (ABUD et al., 2010).

With regard to the seeds width, it was noticed that there was a ranging from 0.39 to $0.53 \mathrm{~cm}$, with 
predominance in the $0.46-0,47 \mathrm{~cm}$ where $50 \%$ of the evaluated seeds were concentrated (Figure 7).

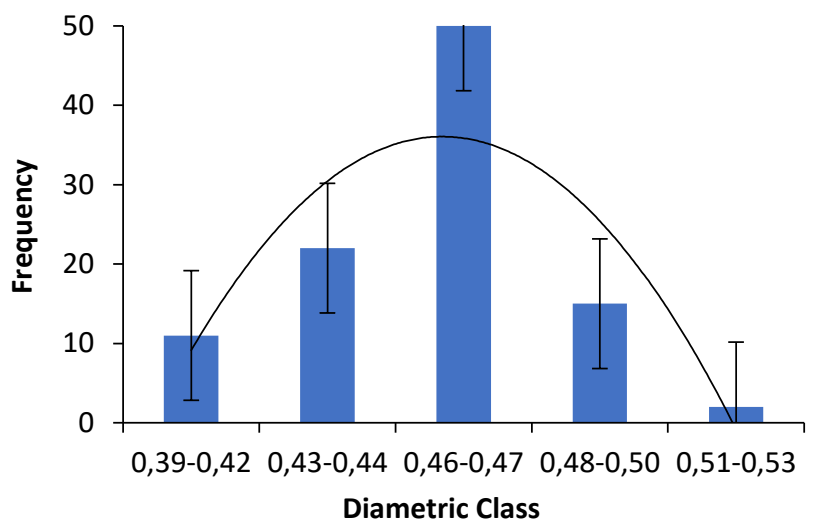

Figure 7. Seeds width's (cm) frequency (\%) of Poincianella pluviosa var. peltophoroides.

According to Carvalho \& Nakagawa (2012), the seed with larger dimensions, in length, width or thickness, are results of better nutrition during its development, thus the embryo will be much more developed and formed, with a larger amount of reserve substances, therefore, may considering them more resistant.

To Alves at al. (2005), seeds with larger dimensions have been correlated with higher rates of initial seedling growth, which would increase the probability of success during their establishment, since the fast growth of root and aboveground would enable the plant to take advantage of nutritional and hydric reserves of the soil and perform photosynthesis.

For the thickness, the dimensions ranged between 0.074 to $0.200 \mathrm{~cm}$, and presented a greater frequency and variation of 0.126 to $0.1250 \mathrm{~cm}$, where $58 \%$ of the seeds were concentrated (figure 8).

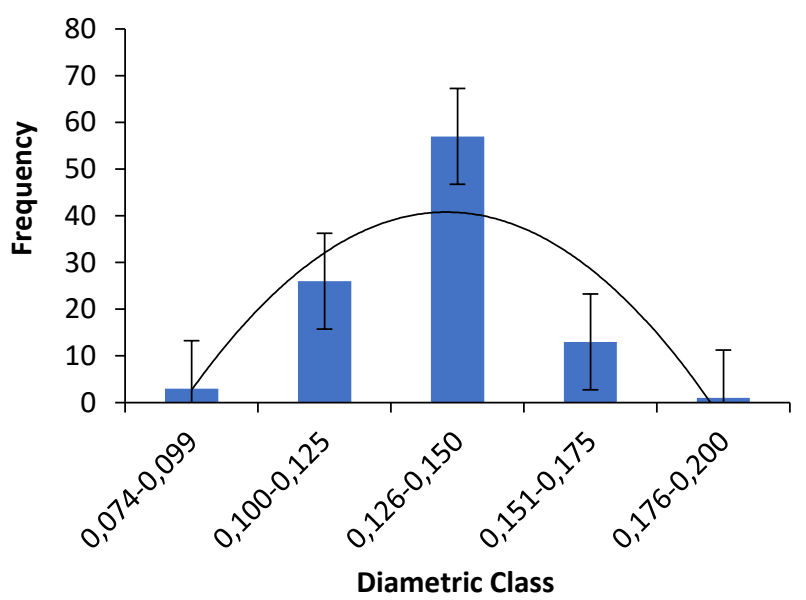

Figure 8. Seed thickness (cm) frequency (\%) of Poincianella pluviosa var. peltophoroides. The seeds with higher thicknesses may be considered with greater physiological qualities.

For Vieira \& Gusmão (2008), biometric variations can be caused by genetic variability or phenotypic plasticity, or even represent species variety. Braga et al. (2013) reinforce that it is important to know the biometric characteristics so that we can know the difference of species in the genus, in the relationship of this variability with environmental factors.

The seed that showed higher lenghts, thicknesses and widths are considered the most vigorous or resistant, this is, due to the higher reserves' concentration, succeeding the most viable for the seedlings' production. The seed's size is one of the factors that can influence the seedlings' growth and development, since the larger seeds have greater reserve content in their cotyledons, reflecting in a higher plant growth, enabling success in seedling formation (NIETSCHE et al., 2004).

The average seed weight was $0.28 \mathrm{~g}$, while the weight of 100 seeds was $28.57 \mathrm{~g}$, in a kilogram of seed it has an average of 3.500 seeds. Approximate results are reported in the studies by Nogueira et al. (2012), with seeds of Luetzelzurgia auriculata, the species Pau-Pedra. These authors noticed that the seeds weight ranged from 0.23 to $0.68 \mathrm{~g}$, with the weight of 100 seeds registering $28.57 \mathrm{~g}$ and thus, leading to the conclusion that one kilogram of Sibipiruna seeds contains 3,500 seeds. Carvalho et al. (2012) emphasize that seeds that present higher weight are able to remain more nurtured during their embryonic development, becoming more vigorous with bigger amounts of reserves, helping in embryonic functions.

The knowledge of the biometric variation of fruit and seed characters is important for the formation of germplasm banks and for these characteristics improvement, either in the sense of increase or uniformity, which can be explored by improvement programs.

\section{CONCLUSIONS}

The Poincianella pluviosa var. peltophoroides fruits show higher differences in the biometric thickness and width variables, with the length variable being the most uniform distribution of fruits.

The Poincianella pluviosa var. peltophoroides species have higher biometric uniformity in their seeds, being a favorable criterion for their propagation.

The informations about fruits and seeds' morphological characteristics of Poincianella pluviosa var. peltophoroides are useful for better recognition of the species, in addition to filling a gap in the literature that is scarce. 


\section{ACKNOWLEDGMENTS}

To LabNut (Laboratory of Mineral Plant Nutrition) and the research group Sustainable Development in the Semiarid Region of Northeast Brazil /CNPq.

\section{REFERENCES}

ABUD, H.F. et al. Morfologia de sementes e plântulas de cártamos. Revista Ciência Agronômica, v.41, n.2, p.259-265, 2010.

ALVARES, C.A. et al. Köppen's climate classification map for Brazil. Meteorologische Zeitschrift, v.22, n.6, p.711-728, 2014.

ALVES, E.U. et al. Influência do tamanho e da procedência de sementes de Mimosa caesalpiniifolia Benth. sobre a germinação e vigor. Revista Árvore, v.29, n.6, p.877-885, 2005.

BEZERRA, F.T.C. et al. Biometria de frutos e sementes e tratamentos pré-germinativos em Cassia grandis L. f. (Fabaceae). Semina: Ciências Agrárias, v.33, p.2863-2876, 2012.

BRAGA, L.F. et al. Morfometria de sementes e desenvolvimento pós-seminal de Schizolobium amazonicum Huber (Ducke) Fabaceae. Científica, v.41, n.1, p.01-10, 2013.

CARVALHO, J.E.U. et al. Características físicas e físico-químicas de um tipo de bacuri (Platonia insignis Mart.) com rendimento industrial superior. Revista Brasileira de Fruticultura, v.25, p.326328, 2003.

CARVALHO, N.M.; NAKAGAWA, J. Sementes: ciência tecnologia e produção. 5.ed. Jaboticabal: FUNEP, 2012.

CRUZ, E.D. et al. Biometria de frutos e sementes de jatobá-curuba (Hymenaea intermedia Ducke, Leguminosae - Caesalpinioideae). Revista Brasileira de Botânica, v.24, n.2, p.161-165, 2001.

ENDRESS, P.K. Diversity and evolutionary biology of tropical flowers. 1.ed. Cambridge: Cambridge University Press, 1994.

HALLÉ, F. at al. Tropical trees and forest: an architectural analysis. Berlin: Springer Verlag, 1978.

LORENZI, H. Árvores brasileiras: manual de identificação e cultivo de plantas arbóreas nativas do Brasil. 1.ed. Nova Odessa: Plantarum, 1992.

LORENZI, H. Árvores brasileiras: manual de identificação e cultivo de plantas arbóreas nativas do Brasil. 5.ed. São Paulo, Instituto Plantarum, 2008.

MASCARÓ, L.E.; MASCARÓ, J. Vegetação urbana. 2.ed. Porto Alegre: Editora Mais Quatro, 2005.

NIETSCHE, S. et al. Tamanho da semente e substratos na germinação e crescimento inicial de mudas de Cagaiteira. Ciência e Agrotecnologia, v.28, n.6, p.1321-1325, 2004.

NOGUEIRA, F.C.B. et al. Efeito da temperatura e luz na germinação de sementes de Luetzelburgia auriculata (Alemão)
Ducke - Fabaceae. Revista Acta Botanica Brasilica, v.26, p.772778, 2012.

PAIVA, A.F. Estatística. Belo Horizonte: UFMG, 1982.

RODRIGUES, A.C. et al. Biometria de frutos e sementes e grau de umidade de sementes de angico Anadenanthera colubrina (Vell.) Brenan Var. cebil (Griseb.) Altschul procedentes de duas áreas distintas. Revista Científica Eletrônica de Engenharia Florestal, v.4, n.8, p.1-15, 2006.

SANGALI, A. Propagação, desenvolvimento, anatomia e preservação ex situ de Jacaranda decurrens subs. Symmetrifoliolata (Farias \& Proença). 2008. 90p. (Tese de doutorado).

SILVA, L.F. et al. Precipitação interna e interceptação da chuva em duas espécies arbóreas urbanas. Revista da Sociedade Brasileira de Arborização Urbana, v.4, p.32-48, 2009.

SOARES, I.D. et al. Caracterização morfológica de fruto, semente e plântula de Psidium rufum DC. (Myrtaceae). Iheringia, Série Botânica, v.72, n.2, p.221-227, 2017.

SOUTO, P.C. et al. Biometria de frutos e número de sementes de Calotropisprocera (Ait) R. Br. No semiárido da Paraíba. Revista verde de Agroecologia e Desenvolvimento Sustentável, v.3, p.108-113, 2008.

VIDAL, W.N.; VIDAL, M.R.R. Botânica organografia. 3.ed. Viçosa: Imprensa Universitária, 1992.

VIEIRA, F.A.; GUSMÃO, E. Biometria, armazenamento de semente e emergência de plântulas de Talisia esculenta Radlk. (Sapindaceae). Ciência e Agrotecnologia, v.32, p.1073-1079, 2008.

Recebido em 21-03-2020 Aceito em 23-04-2020 